\title{
INADMISSIBILITY OF CIVIL PROCEEDINGS AND ACCESS TO COURT
}

\author{
Agnieszka Golab \\ Ph.D., assistant to judge in the Supreme Court \\ of the Republic of Poland, Warsaw University \\ (Warsaw, Poland)
}

https://doi.org/10.33327/AJEE-18-2.3-a000014

Summary: 1. Introduction. - 2. Historical Background. - 3. Right to Court in Polish Case-law and Jurisprudence. - 4. The Way to View Absolute Procedural Premises. - 5. The Impact of Party Autonomy on Ending Polish Civil Proceedings without a Judgement. 6. Concluding Remarks.

By instigating civil proceedings a plaintiff intends to obtain a final and unequivocal judgement on the merits regulating a legal situation which had been unclear prior to the lawsuit. However, reaching this goal will not always be possible. The court might be obliged to reject the lawsuit or annul the proceedings due to formal reasons (cf. Article 199 and article 355 of the Polish Code of Civil Procedure). Such situations give room to considerations whether purely formal, procedural decisions violate litigants' right to court in the aspect of 'right to judgement', i.e. a right to a verdict substantively adjudicating the merits of the case. The author analyzes this issue with reference to the so-called absolute procedural prerequisites (Germ. Prozessvoraussetzungen) and their impact on constitutional and treaty-based guarantees of access to court.

Keywords: Access to Court, Right to a Judgement, Inadmissibility of Proceedings, Civil Process.

\section{INTRODUCTION}

The civil process is typically brought to completion with a judgement in which the court adjudicates the merits of the case. However, such a scenario is not always possible due to the inadmissibility of proceedings. Such a situation raises the question whether the procedural guarantees of the right to court - especially in the aspect of the 'right to a judgement' - are preserved under these circumstances. The importance of this issue is hard to ignore, as the right to court constitutes a fundamental legal concept, enshrined not only on a national (e.g. constitutional) level, but also in international treaties and conventions. 


\section{HISTORICAL BACKGROUND}

The idea of the right to judicial protection has been long established in the European legal culture. It clearly manifested itself in the German legal doctrine of $19^{\text {th }}$ century, when the concept of the 'right to lawsuit' (Klagerecht) was hotly debated. ${ }^{1}$ Simultaneously, the concept of public procedural rights attributed to a party in her dealings with the State, was also steadily developed by legal scholars such as G. Jellinek and P. Laband. ${ }^{2}$ In this context one should also bear in mind the consistent emergence of the concepts of 'legal state' and 'rule of law' which were accompanied by the idea of the right to court. As already mentioned, these concepts were subsequently enacted in numerous legal acts from the realm of public international law. ${ }^{3}$ As a result of developments in this sphere, the right to judicial protection - currently defined as the possibility of requesting the court to examine the case and pass a judgement on the merits - was subject to the process of constitutionalization in respective national legal orders. Even if a given legal system does not proclaim the right to court directly on a constitutional level, it is common for such systems to introduce similar concepts in either procedural or constitutional acts. This observation can be exemplified by the doctrinal concept of Justizgewährungsanspruch, which is derived from the overall content enacted in the German constitution. ${ }^{4}$

As regards the Polish legal order, the right to court is proclaimed in Article 45 (1) of the Constitution of the Republic of Poland of $1997 . .^{5}$ Substantial headway towards reaching this stage was made in 1989 when the principle of democratic state of law was introduced to the preceding Polish Constitution of 1952. It is worth mentioning that Polish constitutions from the pre-war period - dating back to the times when Polish civil procedural law was still at the early stages of its development - did not directly regulate the right to judicial protection, nor the

1 Cf. in international context e.g. N Klamaris, 'Das prozessuale Grundrecht auf Justizgewährung am Beispiel der griechischen Rechtsordnung' in P Gottwald, H Prütting, Festschrift für Karl Heinz Schwab zum 70. Geburtstag (Beck 1990) 269 ff; S Detterbeck, 'Streitgegenstand, Justizgewährungsanspruch und Rechtsschutzanspruch' (1992) No 1-2, AcP 325 ff; WJ Habscheid, 'Der Anspruch auf Rechtspflege' (1954) No 3-4 ZZP, 188 ff; J Farkas, 'Bemerkungen zur Lehre vom Rechtspflegeanspruch' in W F Lindacher, W J Habscheid (eds), Festschrift für Walter J. Habscheid zum 65. Geburtstag (Bielefeld 1989) 83 ff; KH Schwab, 'Zur Wiederbelebung des Rechtsschutzanspruchs' (1968) No 5-6 ZZP 412 ff; A Blomeyer 'Der Rechtsschutzanspruch im Zivilprozess' in K A Bettermann, A Zeuner (eds), Festschrift für Eduard Bötticher zum 70. Geburtstag (Duncker Humblot 1969) $61 \mathrm{ff}$; Cf. also in the Polish legal doctrine H Mądrzak 'Prawo do sądu jako gwarancja ochrony praw człowieka (stadium na tle polskiego prawa konstytucyjnego, prawa cywilnego materialnego i procesowego)' in L Wiśniewski (ed) Podstawowe prawa jednostki i ich sądowa ochrona (Wydawnictwo Sejmowe 1997) 186 ff; W Berutowicz, 'Funkcja procesu cywilnego w oświetleniu nauki o tzw. prawie skargi' in Księga pamiątkowa ku czci Kamila Stefki (Warszawa-Wrocław 1967) 9 ff; W Broniewicz, 'Pojęcie prawa do powództwa w nauce polskiego procesu cywilnego' in E Łętowska (ed), Proces i prawo. Rozprawy prawnicze. Ksiega pamiątkowa ku czci Jerzego Jodłowskiego (Wroclaw Warszawa Kraków Gdańsk Łódź 1989) 277 ff.

2 G Jellinek, System der subjektiven öffentlichen Rechte (Mohr Siebeck 1882); P Laband, Das Staatsrecht des Deutschen Reiches (vol 3, Laupp 1901).

3 Cf. Article 10 of Universal Declaration of Human Rights, Article 6 of European Convention of Human Rights, Article 14 of International Convention on Civil and Political Rights, Article 47 sentence 2 of Charter of Fundamental Rights of the European Union.

4 H J Papier, 'Justizgewähranspruch' in J Isensee, P Kirchhof (eds), Handbuch des Staatsrechts. Grundrechte: Wirtschaft, Verfahren, Gleichheit (vol 8, Heidelberg 2010), $492 \mathrm{ff}$.

5 Z Czeszejko-Sochacki, 'Prawo do sądu w świetle Konstytucji Rzeczypospolitej Polskiej (ogólna charakterystyka)’ (1997) No 11-12 Państwo i Prawo 86 ff. 
right to court. ${ }^{6}$ Constitutional considerations were not at the center of attention when the first Polish Code of Civil Procedure was enacted in 1930, nor in the socalled March Constitution of 1921.

\section{RIGHT TO COURT IN POLISH CASE-LAW AND JURISPRUDENCE}

The Polish Constitutional Tribunal ${ }^{7}$ holds that the right to court consists of three basic components: firstly, the right of access to court, i.e. the possibility of instigating civil proceedings before a competent, impartial and independent court; secondly, the right to the adequate shape of civil proceedings, which is manifested by the right to a fair trial and transparent civil process; and thirdly, the right to judgement, i.e. the right to obtain a final and binding adjudication of the case by the court. ${ }^{8}$ As of today, the right to court in its triple form permeates the entirety of Polish civil proceedings.

In the light of the abovementioned aspects of the right to court, it appears that a plaintiff intends to achieve a final and unequivocal regulation of his legal situation, which had been unclear prior to the lawsuit. However, as already mentioned, reaching this goal will not always be possible. The court might be obliged to reject the lawsuit or annul the proceedings due to formal reasons (cf. Article 199 PCCP and article 355 PCCP). ${ }^{9}$ Such situations give room to considerations whether purely formal, procedural decisions do not violate litigants' right to court, especially in the aspect of 'right to judgement', i.e. a verdict on the merits of the case.

The Polish jurisprudence as well as the judiciary present two stances in this regard. The first one claims that procedural provisions which establish criteria of (in)admissibility of civil proceedings constitute an inherent premise of the right to court and should not be a priori qualified as its infringement or limitation. ${ }^{10}$ As far as the opposite view is concerned, rejecting a lawsuit which was inadmissible $a b$ initio or annulling the proceedings which became inadmissible at a later stage of civil process, amounts to blocking access to court, which can be considered as justified only if it meets two criteria of legality (cf. Article 31 (3) of the Constitution of the Republic of Poland). ${ }^{11}$ Firstly, it

$6 \quad$ Cf. Article 98 of the Constitution of 17 March 1921 and Article 68 (1 and 4) of Constitution of 23 April 1935.

7 Judgement of the Polish Constitutional Tribunal of 12 March 2002 P 9/01 (OTK ZU A 2002) No 2 item 14; judgement of the Polish Constitutional Tribunal of 4 November 2010 (OTK ZU A 2010) No 9 item 96; judgement of the Polish Constitutional Tribunal of 11 December 2002, SK 27/01, (TK ZU A 2002) No 7 item 93; judgement of the Polish Constitutional Tribunal of 8 May 2006, SK 32/05 (OTK ZU A 2006) No 5 item 54; judgement of the Polish Constitutional Tribunal of 16 November 2004, P 19/03, (OTK ZU A 2004) item 106.

8 Judgement of the Polish Constitutional Tribunal of 9 June 1998, K 28/97, (OTK 1998) No 4 item 50; judgement of the Polish Constitutional Tribunal of 10 July 2000, SK 12/99 (OTK 2000) No 5 item 143.

9 Polish Code of Civil Proceedings of 17 November 1964 (unified version: Journal of Law 2018 item 1360) (hereinafter - PCCP).

10 P Grzegorczyk, K Weitz, 'Komentarz do art. 45 Konstytucji RP’ in M Safjan, L Bosek (eds), Konstytucja RP (Legalis 2016) point 45 and point 56.

11 JMucha, Zawisłość sprawy w procesie cywilnym (Wolters Kluwer Polska 2014) 136; A Kubiak, Konstytucyjna zasada prawa do sądu w świetle orzecznictwa Trybunału Konstytucyjnego (Wydawnictwo Uniwersytetu Łódzkiego 2006) 271-271 and 302; B Adamiak, J Borkowski, 'Instytucje procesowe wyznaczające granice prawa do sądu' in Państwo prawa. Administracja. Sądownictwo. Prace dedykowane Prof. dr hab. Januszowi Łętowskiemu w 60. rocznice urodzin (Warszawa 1998) 311; P Hofmański, A Wróbel in L Garlicki (ed), Konwencja o Ochronie Praw Człowieka i Podstawowych Wolności. Komentarz do artykułów 1-18 (vol 1, CH Beck 2010) 295-296. Cf. A Olaś, Umorzenie procesu cywilnego (CH Beck 2016) 122. 
must be enacted in a legal act (e.g. in the Code of Civil Procedure or in a different act of comparable status), and secondly, it cannot violate the essence of the right to court. ${ }^{12}$ A similar approach has been presented in the case-law of the Polish Constitutional Tribunal. It can be illustrated by a judgement of 10 May 2000, K 21/99, ${ }^{13}$ in which the Tribunal held that shaping court proceedings in accordance with specific procedural premises constitutes a significant and real limitation of the right to court, which is nonetheless necessary to respect values which are commonly cherished in a democratic state of law. The formal requirements, which are universally adopted and applied in all sorts of court proceedings, set boundaries within which the right to court can be correctly and duly implemented. According to the Tribunal, it is necessary to ascertain whether these procedural requirements and procedural premises are not overly rigorous and whether they can be assessed as proportionate with regard to the aim that they serve. ${ }^{14}$ By comparison, the European Court of Human Rights holds that the procedural rights, which are enshrined in the Convention, must be guaranteed and implemented in a practical and effective way. Therefore, a state would contradict this concept, if it adopted rules excluding a significant group of civil claims form the court jurisdiction in an unlimited and unrestricted way. The Court opposed the practice consisting in granting immunities to large groups of potential defendants, as it would adversely affect plaintiffs' right to court in a disproportionate way. Hence, the Court separately assesses the circumstances of each and every case presented to him, and reaches a conclusion whether the limitations of the right to court can be appraised as justifiable. ${ }^{15}$

\section{THE WAY TO VIEW ABSOLUTE PROCEDURAL PREMISES}

In order to evaluate the stances presented above, one can start with a reference to the right to court understood as a possibility of instigating civil proceedings. The civil process, in which access to court and all subsequent components of the right to court can be brought to fruition, is governed by a set of rules of procedural law. As a matter of fact, the lawmaker is not only supposed to provide a detailed framework in which the civil process is set, but also to establish basic prerequisites which determine effective launching of proceedings and the possibility of obtaining a verdict on the merits. These requirements constitute a foundation on which structural elements of the litigation are set. Although their existence plays a fundamental part in determining effective access to court, they are not entirely static and they can evolve over the decades and be subject to modification by the lawmaker. ${ }^{16}$

When discussing elements conditioning the right to court in the aspect of the 'right to a judgement', prominence should be given to absolute procedural prerequisites (Germ.

\footnotetext{
12 Olaś (n 11) 122. Cf. Mucha (n 11) 123-142.

13 (OTK 2000) No 4 item 109.

14 Cf. Judgement of the Polish Constitutional Tribunal of 27 May 2008, SK 57/06 (OTK-A 2008) No 4 item 63; judgement of the Polish Constitutional Tribunal of 1 July 2008, SK 40/07 (OTK-A 2008) No 6 item 101; judgement of the Polish Constitutional Tribunal of 10 May 2000, K 21/99 (OTK 2000) No 4 item 109.

15 Judgement of the European Court of Human Rights of 14 January 2014, 34356/06.

16 Cf. P van Dijk in P Van Dijk et al. (eds), Theory and Practice of the European Convention on Human Rights (Intersentia 2006) 570 ('the right of access to the courts is not absolute [...] by its very nature calls for regulation by the State, regulation which may vary in time and in place according to the needs and resources of the community and of individuals. [...] In laying down such regulation, the Contracting States enjoy a certain margin of appreciation').
} 
Prozessvoraussetzungen). The view advocating the necessity to single out circumstances which preliminarily condition not the legitimacy, but the admissibility of the plaintiff's claim, gained importance in the $19^{\text {th }}$ century. As of today, absolute procedural prerequisites can be defined as fundamental concepts whose existence or non-existence determines the court's competence to examine the merits of the case. The analysis of Polish civil procedural law as well as comparative studies have shown that absolute procedural prerequisites can be regulated directly in the code of civil proceedings or their existence can be deduced from the overall structure governing the civil process. ${ }^{17}$ They pertain to different aspects of procedural law, thus creating an integral set of premises determining the access to court.

These procedural prerequisites, just as any other formal requirements which condition the admissibility of adjudicating the merits of the case, should not be a priori perceived as a restriction or limitation of procedural rights, because they constitute an inherent part of the constitutional standard of access to court. ${ }^{18}$ On one hand, absolute procedural prerequisites (Germ. Prozessvoraussetzungen) define the framework in which the right to a judgement' can be effectuated, and on the other hand, they contribute to shape the content of the right to court, by laying down necessary - although not exhaustive conditions for its proper and legitimate implementation. ${ }^{19}$ It should be emphasized that each procedural prerequisite - especially an absolute on $\mathrm{e}^{20}$ - has been designed to protect a specific set of values. The analysis of each of them reveals the underlying ratio legis. For instance, international jurisdiction can be defined as a competence of the courts' of a given state to grant legal protection, which is justified by a sufficient connection between the case in question and the legal order of that state. This competence is interlinked with an obligation to take advantage of it, meaning that a Polish court is bound to examine the merits of the case. ${ }^{21}$ As regards another absolute procedural prerequisite, i.e. the competence of courts of general jurisdiction to examine the case (cf. Article 2 PCCP) its ratio legis consists in assigning civil cases in accordance with the scope of competence and specialization of such courts to examine civil cases. ${ }^{22}$ It is also easy to understand the reasoning behind such absolute procedural requirements as lis pendens and res iudicata. ${ }^{23}$ It is absolutely legitimate to assume that the court should refuse to substantively examine the case and pass a judgement on the merits if the same claim had already been adjudicated on the same factual grounds between the same parties. This is justified by the authority

17 Cf. H Trammer, Następcza bezprzedmiotowość procesu cywilnego (Kraków 1950) 20.

18 P Grzegorczyk, K Weitz, 'Komentarz do art. 45 Konstytucji RP' in M Safjan, L Bosek (eds), Konstytucja RP (Legalis 2016) point 45 and point 56; M Pilich, 'Wpływ orzeczeń Trybunału Konstytucyjnego na Kodeks postępowania cywilnego' in (ed) T Ereciński, K Weitz, Orzecznictwo Trybunału Konstytucyjnego a Kodeks postępowania cywilnego. Materiały Ogólnopolskiego Zjazdu Katedr i Zakładów Postępowania Cywilnego, Serock k. Warszawy, 24-26 września 2009 (Warszawa 2010).

19 Cf. T Zembrzuski, Nieważność postępowania w procesie cywilnym (Wolters Kluwer Polska 2017) 527-530.

20 K Weitz, Jurysdykcja krajowa w postępowaniu cywilnym (Wydawnictwo Prawo i Praktyka Gospodarcza 2005) 390; P Grzegorczyk, Immunitet państwa w postępowaniu cywilnym (Wolters Kluwer 2010) 298; Cf. Z Resich in J Lapierre, J Jodłowski, Z Resich, T Misiuk-Jodłowska, K Weitz (eds), Postępowanie cywilne (Wolters Kluwer 2016) 72.

21 Weitz (n 20) 113; P Grzegorczyk, 'Reżim procesowy immunitetu państwa w postępowaniu cywilnym' (2010) No 1 Przegląd Sądowy 23-24.

22 Cf. E Gapska, 'Wyłączenie drogi sądowej w sprawach cywilnych w świetle Konstytucji RP' in $€$ Błaszczak (ed), Konstytucjonalizacja postępowania cywilnego (Presscom sp z oo 2015) $69 \mathrm{ff}$.

23 Cf. Judgement of the Polish Constitutional Tribunal of 4 November 2003, SK 30/02, (OTK-A 2003) No 8 item 84 . 
and highest good of the whole judicial system - including parties to the proceedings - as well as stability and transparence of legal relations. It would be detrimental to the parties and to the judicial system if another judgement was passed despite the already existing res judicata or the state of lis pendens. Therefore, in such cases the Polish court is bound to reject the lawsuit ${ }^{24}$ or annul the proceedings, ${ }^{25}$ thus ending civil process without a judgement on the merits. By the same token, the role of absolute procedural prerequisites with regard to the subjects of the proceedings is also of great significance. For instance, the capacity to be a party to civil proceedings is indispensable to be a beneficiary of procedural rights and to partake in procedural burdens. If a party lacks this capacity, the civil process is flawed at its core and cannot be continued. ${ }^{26}$ Although article 45 (1) of the Polish Constitution grants the right to court to 'everybody', it does not mean that absolutely all persons and entities enjoy the capacity to be a party to civil proceedings, nor that they can unconditionally benefit from it.

In conclusion, existence of each absolute procedural requirement (both positive ones and negative ones) serves the protection of a specific set of values, which were considered by the lawmaker as so fundamental that the implementation of the right to court (in the aspect of the 'right to a judgement') was conditioned upon their existence. ${ }^{27}$ The protective function of these absolute procedural prerequisites is constructive in nature, as it gives space to shape the civil proceedings in accordance with these crucial values. ${ }^{28}$ The significance of this issue is underlined by the Polish lawmaker himself, as he orders the court to taking into account the lack of absolute procedural requirements ex officio at all stages of the proceedings (cf. Article 202 sentence 3 in fine PCCP). It follows that procedural requirements which determine the right to court in the aspect of the right to a judgement, do not restrict it, but they co-create the content of the proper implementation of this fundamental right (cf. Article 379 point 1-3 PCCP, Article 1099 $\S 2$ PCCP, Article 1113 sentence 3 PCCP).

\section{THE IMPACT OF PARTY AUTONOMY ON ENDING POLISH CIVIL PROCEEDINGS WITHOUT A JUDGEMENT}

The right to court in the aspect of adequate (lawful) shape of civil proceedings implies the necessity to regulate it in accordance with constitutional and treaty-based standards of fair trial. The creation of legal framework of civil proceedings and specific rules governing it, has been entrusted with the 'ordinary' lawmaker. It concerns a wide spectrum of issues which go far beyond the question of absolute procedural requirements. ${ }^{29}$ The legislative activity in this regard should respect the constitutional guarantees of access

$24 \quad$ Article 199 PCCP.

25 Article 355 PCCP.

26 Cf. P Kaczmarek, 'Prawo do sądu a zdolność sądowa' (2005) No LXXIII PPiA, 93 ff.

27 Cf. W Brehm, 'Einleitung' in R Bork, H Roth (eds) Stein/Jonas Kommentar zur Zivilprozessordnung (vol 1, Mohr Siebeck 2014) 108-109, who mentions the „Schutzfunktion” of respective procedural prerequisites.

28 Cf. Z Resich, Przesłanki procesowe (Wydaw. Prawnicze 1966) 104. Cf. W Berutowicz, Postępowanie cywilne w zarysie (Państwowe Wydawn. Naukowe 1984), 99 and 105.

29 J Meyer-Ladewig, Konvention zum Schutz der Menschenrechte und der Grundfreiheiten (Nomos 2003) 98-101; F C Mayer in U Karpenstein, F C Mayer (eds), Konvention zum Schutz der Menschenrechte und Grundfreiheiten (Beck 2015) 176. Cf. N Półtorak in A Wróbel (ed), Karta Praw Podstawowych Unii Europejskiej. Komentarz (CH Beck 2013), 1225-1227. 
to court, and it should aspire to set conditions for its proper implementation. ${ }^{30}$ The accuracy of these conclusions is confirmed by comparative studies. ${ }^{31}$ In this context, it should be emphasized that annulment of proceedings which transpires as a result of a 'subsequent needlessness' of verdict on the merits (cf. Article $355 \$ 1$ PCCP) does not infringe on the right to court, neither. In this case, bringing civil process to an end without a judgement results from expiry or discontinuation of the aim which urged the plaintiff to file a lawsuit.

As regards the relation between access to court and annulment of proceedings in Polish civil process (Article 355 PCCP), it is also important to consider the role of the principle of party autonomy. This principle should be analyzed in the context of the constitutional guarantees of freedom..$^{32}$ From the positive perspective it manifests itself by a plaintiff's liberty to instigate civil proceedings, take advantage of the procedural power to act and influence the course of the proceedings including the subject-matter of the lawsuit (petitum). From the negative perspective it can be exemplified bylimiting the court's power to adjudicate the case in its entirety or in part for instance by withdrawing or narrowing the demand or by reaching a court settlement (Art. 203 PCCP, Art. 223 PCCP). The principle of party autonomy also comes into play when the court forgoes examination of the case following litigants' passivity - in this case the parties to the proceedings must accept responsibility for desisting from contributing a so-called 'procedural impulse' to the civil process (cf. the French institution of péremption d'instance and its Polish counterpart regulated in Article 182 PCCP). It is worth mentioning in this context that

$30 \quad$ Cf. Zembrzuski (n 19) 527-530.

31 In German law cf. H-J Papier, 'Justizgewähranspruch' in J Isensee, P Kirchhof (eds), Handbuch des Staatsrechts, Bd. VIII. Grundrechte: Wirtschaft, Verfahren, Gleichheit (Heidelberg 2010) 499 who states the following: ,Der Zugang zu den Gerichten sowie das anschließende gerichtliche Verfahren unterliegen mannigfaltigen Reglementierungen der einfach-gesetzlichen Prozessordnungen. Die Gesetzgebung ist in der Lage, zumutbare und sachlich begründete Zulässigkeitsvoraussetzungen für das individuelle Rechtsschutzbegehren zu normieren (Formen, Fristen, Partei- und Prozessfähigkeit, Prozessvertretung, Rechtsschutzbedürfnis, Prozesskostenregelung). Bei der Ausgestaltung der Prozessgesetze steht dem Gesetzgeber ein weiter Gestaltungsspielraum zu. Seine Grenzen findet er dort, wo der Zugang zu einem Gericht bzw. das anschließende Rechtsschutzverfahren in unzumutbarer, aus Sachgründen nicht mehr zu rechtfertigenden Weise erschwert werden. Daneben sind die speziellen Rechtsschutzstandards der besonderen Justizgrundrechte (Article $101 \mathrm{ff} \mathrm{GG)} \mathrm{zu} \mathrm{wahren;} \mathrm{E} \mathrm{Benda,} \mathrm{A} \mathrm{Weber,} \mathrm{'Der} \mathrm{Einfluss} \mathrm{der}$ Verfassung im Prozessrecht' (1983) No 3 ZZP 292-293. In Greek law cf. N Klamaris, 'Die „Parteibezogenen” bzw „Persönlichen“ Prozessvoraussetzungen nach dem griechischen Zivilprozessrecht' in R Geimer, R Schutze, T Garber (eds) Europäische und Internationale Dimensionen des Rechts. Festschrift für DaphneAriane Simotta (Lexis Nexis 2012) $291 \mathrm{ff}$ - the author claims that ,Recht auf Justizgewährung und Prozessvoraussetzungen. Ein Spannungsverhältnis oder eine funktionelle dialektische Beziehung zwischen zwei kommunizierenden Gefäßen?', concluding that existence of absolute procedural requirements does not affect, nor limit the right to court; cf. also N Klamaris, 'Das prozessuale Grundrecht auf Justizgewährung am Beispiel der griechischen Rechtsordnung' in P Gottwald, H Prütting (eds), Festschrift für Karl Heinz Schwab zum 70. Geburtstag (Beck 1990) 269 ff. In English legal doctrine cf. P Van Dijk in P Van Dijk et al (eds), 'Theory and Practice of the European Convention on Human Rights' (Intersentia 2006) 570, ('the right of access to the courts is not absolute [...] by its very nature calls for regulation by the State, regulation which may vary in time and in place according to the needs and resources of the community and of individuals. [...] In laying down such regulation, the Contracting States enjoy a certain margin of appreciation'). In French law cf. J Vincent, S Guinchard, Procédure civile (Dalloz 2001) 139, who claim that 'La mise en œuvre du droit à un recours juridictionnel peut être subordonnée à des conditions, la valeur constitutionnelle de ce droit ne le transformant pas en droit absolu et illimité. Le législateur peut lui apporter des atteintes non substantielles. Ainsi, l'intérêt à agir est une condition de la reconnaissance du droit au recours juridictionnel : il est d'ailleurs visé par la décision du Conseil constitutionnel du 13 août 1993, décision qui ne reconnaît ce droit « qu'aux seules personnes intéressées'.

32 P Grzegorczyk, 'O konstytucjonalizacji prawa procesowego cywilnego' (2012) No 2 Kwartalnik Prawa Prywatnego 298-299 and 306-307. 
the principle of party autonomy is not perceived as absolute in the Polish constitutional and procedural law, as it is accompanied by other instruments allowing for a fair balance between it and other values which are legally protected (cf. the 'controlled' principle of party autonomy). The Polish Code of Civil Procedure also acknowledges the fact that the access to court is not only oriented towards the plaintiff, but it also honors the rights of a defendant. The Polish civil procedural law provides the defendant with mechanisms which allow him to decide about the end of proceedings on a par with a plaintiff (cf. Article 203 (1) in principio PCCP; Article 223 PCCP). It plays a significant role when it comes to closing civil proceedings without a judgement. ${ }^{33}$

\section{CONCLUDING REMARKS}

In the light of the above conclusions, it is controversial to assess the constitutionality of annulment of proceedings from the perspective of Article 31 (3) of the Constitution of the Republic of Poland. This regulation is based on the a priori assumption that provisions regulating inadmissibility of civil claims constitute a limitation of the access to court, which can be viewed as acceptable only on condition of its proportionality. ${ }^{34}$

A separate question arises on the ground of Article 77 (2) of the Constitution of the Republic of Poland, according to which it is justifiable to bar access to court by way of a legal provision directly regulated in the Constitution. It is exemplified by articles establishing formal procedural immunity of parliamentarians (cf. Article 105 and 108 of the Constitution of the Republic of Poland). The refusal of a House of Parliament to grant permission to initiate court action against a parliamentarian results in barring access to court in this regard. ${ }^{35}$ In legal doctrine it is universally held that such a scenario can also ensue from jurisdictional immunities deriving from international public law (cf. Article 9 of the Constitution of the Republic of Poland).

Procedural requirements, which set the boundaries of admissibility and inadmissibility of proceedings, are subject to verification with regard to their coherence with constitutional standards as well as their compatibility with procedural guarantees enshrined in treaties and conventions. ${ }^{36}$ On an international level, the issue of immunities sparked a special interest. ${ }^{37}$ The controversy regards immunities stemming from public international law as well as procedural immunities with an internal reach such as abovementioned parliamentary immunity. The European Court of Human Rights holds that beneficiaries

33 Grzegorczyk, (n 32) 298-299 and 306-307; R Stürner, 'Verfahrensgrundsätze des Zivilprozesses und Verfassung' in W Grunsky (ed), Festschrift für Fritz Baur (Mohr Siebeck 1981) 650 ff; P Gilles, 'Zivilprozess und Verfassung - Betrachtungen zum Thema aus deutscher Sicht' in Studia in honorem Pelayia YessiouFaltsi (Athens-Thessaloniki 2007) 218. Cf. W Głodowski, 'Cofnięcie pozwu w świetle konstytucyjnej zasady równości’ in Z Niedbała (ed), Prawo wobec dyskryminacji w życiu społecznym, gospodarczym $i$ politycznym (Warszawa 2011) $75 \mathrm{ff}$.

34 Cf. Olaś (n 11) 122; Mucha (n 11) 134; Kubiak (n 11) 271-271 and 302; Adamiak, Borkowski, (n 11) 311.

35 P Grzegorczyk, K Weitz, 'Komentarz do art. 77 Konstytucji RP’ in M Safjan, L Bosek (eds), Konstytucja RP (Legalis 2016) point 137.

36 Pilich (n 18) 371-372; J Człowiekowska, 'Prawo do sądu jako publiczne prawo podmiotowe' (2006) No 5, Zeszyty Naukowe Uniwersytetu Jagiellońskiego 180; P Grzegorczyk, K Weitz, 'Komentarz do art. 45 Konstytucji RP' in M Safjan, L Bosek (eds), Konstytucja RP (Legalis 2016) points 56, 88 and 117.

37 Cf. D Leipold, 'Immunität versus Rechtsschutzgarantie' in Festschrift für Gerhard Lüke zum 70. Geburtstag (Beck 1997) 353 ff; E J Habscheid, 'Die durch art. 6 I EMRK beschränkte Immunität internationaler Organisationen im Erkenntnisverfahren’ (2001) No 5 IPRax 396 ff. 
of those privileges should be narrowly defined. The Court stated in Al-Adsani case that granting immunity to numerous groups or categories of beneficiaries, without any control, reflection and constraint is likely to infringe on the principle of access to court as laid down in article 6 (1) ECHR. ${ }^{38}$ Claims which are encompassed by the immunity should be directly interconnected with the reasons for which the immunity had been granted ${ }^{39}$ It is also important to consider whether a fair balance has been achieved between the public interest in granting immunity and the line of reasoning in favor of the unhindered access to court. ${ }^{40}$ Nonetheless, the European Court of Human Rights has held in a judgement of 14 January 2014 that immunity of a state guaranteed by public international law generally cannot be perceived as a disproportionate restriction of access to court in the meaning of article 6 (1) ECHR. ${ }^{41}$ Considering that access to court constitutes an inherent part of guarantees of a fair trial, certain limitations in this sphere should be viewed as inseparably and naturally connected with it. This statement can be exemplified by restrictions, which are universally accepted by the community of nations as an element of the doctrine of State immunity. This remark carries weight given the relations between constitutional and convention-based guarantees of access to court when it comes to the structure of regulation, as well as its content and overall significance.

In conclusion, whenever litigants turn to court with a request to examine a case and grant legal protection, there is an underlying supposition that - in the ordinary course of action - proceedings should end with a decision on the merits. A party's right to initiate civil proceedings is correlated with the court's obligation to issue a verdict in a way and form prescribed by the law. ${ }^{42}$ Bearing this in mind, it must be acknowledged that the right to court in the aspect of the 'right to a judgement' does not come to fruition when the court issues a purely formal decision, such as a decision to reject a lawsuit (Art. 199 PCCP) or a decision to annul civil proceedings (Art. $355 \$ 1$ PCCP). The right to court in this aspect would be satisfied only if a plaintiff obtained a verdict on the merits. Nonetheless, a situation in which the court rejects a lawsuit or annuls civil proceedings should not be perceived in terms of violating or limiting a party's access to court. The right to court is conditioned upon fulfilling a series of procedural requirements set up in the legislative process, which constitute a prerequisite for adjudicating the case on the merits. As long as a given procedural requirement is not challenged and negatively appraised by a constitutional tribunal, one cannot a priori assume any limitation or restriction in the access to court. A similar approach to this issue was presented in the decision of the Polish Supreme Court of 25 March 2010, I CSK 252/09. The Court argued that annulment of proceedings does not violate Article 45 (1) in connection with Article 2 of the Constitution of the Republic of Poland. The guarantees laid down in these provisions do not provide litigants with a right to demand a judgment on the

38 Judgement of the European Court of Human Rights of 21 November 2001, par. 47. Cf. also judgement of the European Court of Human Rights of 14 January 2014 Jones and others v. the United Kingdom. Cf. M Kloth, Immunities and the Right of Access to Court under Article 6 of the European Convention on Human Rights (Leiden Boston 2010) passim; Dijk (n 16) 571; Meyer-Ladewig (n 29) item 26, 101; Mayer (n 29) 177.

Por. judgement of the European Court of Human Rights of 17 December 2002, A v the United Kingdom, paras. 66-89; judgement of the European Court of Human Rights of 19 June 2001, Kreuz, para. 56; judgement of the European Court of Human Rights of 30 January 2003, Cordova (No. 1), paras. 62-63; judgement of the European Court of Human Rights of 3 June 2004, De Jorio, paras. 29-30.

40 Cf. Judgement of the European Court of Human Rights of 28 October 1998, Osman, paras. 151-153.

41 Cf. Judgement of the European Court of Human Rights of 14 January 2014, 34356/06.

42 Cf. Człowiekowska (n 36) 180. 
merits, but merely with a possibility of instigating civil proceedings and having the case examined. Examination of the merits of the case must be preceded with a positive verification of obligatory procedural requirements. This verification takes place ex officio at all stages of civil proceedings. Its outcome determines the admissibility of passing a judgement (or any other final decision on the merits). The Supreme Court further explained that a constitutional norm does not offer a legal basis for a litigant's right to obtain a substantive ruling in every single case, because the court may be prevented from reaching a judgement due to a lack of legal grounds to appraise the merits of the case. Although a solely procedural closure of civil proceedings should be typically perceived as an exception to the rule, it is not contrary to the Polish Constitution, nor does it infringe a party's right to court. Furthermore, even if we assume that all obligatory prerequisites of admissibility of proceedings are met, the civil process can still draw to a close 'without a judgement'. The reason for such a turn of events may ensue from the procedural autonomy of the parties themselves (i.e. withdrawal of a lawsuit; prolonged discontinuation of proceedings resulting in their annulment; a court settlement). ${ }^{43}$

A different perspective can be adopted only if annulment of proceedings or a court's refusal to annul the proceedings occurred erroneously. In such situations constitutional rights of litigants should be deemed violated. As regards the first scenario, the court simultaneously infringes a judge-imposed interdiction to shy away from administering justice on the merits. The term 'refusal of justice' (Fr. le déni de justice), which can be traced back to the famous Article 4 of the Napoleonic Code ${ }^{44}$ was not codified in the Polish law, ${ }^{45}$ but it is commonly adopted in the legal doctrine. ${ }^{46}$ According to Mateusz Pilich, the court which baselessly refused to adjudicate on the merits, violates the fundamental rules of the democratic state of law and infringes upon parties right to obtain a verdict, i.e. a binding, authoritative clarification of their legal situation. ${ }^{47}$ As regards the second scenario, concerning an erroneous refusal to annul the proceedings, it might manifest itself in the Polish civil procedure by disregarding the principle of procedural autonomy of the parties, which is situated in the sphere of the constitutional principle of freedom. ${ }^{48}$ Both of these situations adversely affect procedural fairness which stems from the right to court in the aspect of fair and adequately shaped proceedings.

43 Cf. Article 203 PCCP, Article 182 PCCP.

44 'Le juge qui refusera de juger, sous prétexte du silence, de l'obscurité ou de l'insuffisance de la loi, pourra être poursuivi comme coupable de déni de justice..

45 H Mądrzak, 'Prawo do sądu jako gwarancja ochrony praw człowieka (stadium na tle polskiego prawa konstytucyjnego, prawa cywilnego materialnego i procesowego)' in L Wiśniewski (ed), Podstawowe prawa jednostki $i$ ich sadowa ochrona (Wydawnictwo Sejmowe 1997) 199; Pilich (n 18) 372.

46 Cf. R Geimer, Internationales Zivilprozessrecht (Köln 2015) 204; E Schumann, 'Das Rechtsverweigerungsverbot. Historische und methodologische Bemerkungen zur Pflicht, das Recht auszulegen, zu ergänzen und fortzubilden' (1968) No 102 ZZP 79 ff.

$47 \quad$ Pilich (n 18) 372.

48 Grzegorczyk (n 32) 298-299. 